\title{
Strategic Aspects of an Eco-Logistic Chain Optimization
}

\author{
Jerzy Korczak $^{1, *}$, Kinga Kijewska ${ }^{2}$ and Stanisław Iwan ${ }^{2}$ \\ 1 Faculty of Economic Science, Koszalin University of Technology, Kwiatkowskiego 6E, 75-343 Koszalin, \\ Poland; korczak1@gazeta.pl \\ 2 Faculty of Engineering and Economics of Transport, Department of Logistics and Transport Systems, \\ Maritime University of Szczecin, 11 Pobożnego Str., 70-507 Szczecin, Poland; \\ k.kijewska@am.szczecin.pl (K.K.); s.iwan@am.szczecin.pl (S.I.) \\ * Correspondence: korczak1@gazeta.pl; Tel.: +48-516-917-282
}

Academic Editor: Manfred Max Bergman

Received: 30 December 2015; Accepted: 29 February 2016; Published: 25 March 2016

\begin{abstract}
The result of ecological aspects being taken into consideration in human activities and aiming at an optimization of the chains of deliveries is an intention to close the loop of deliveries. One of the ways to achieve this aim is an application of the concept of ecologistics. While waste constitutes one of the main elements of ecologistics, it poses the most serious threat to the natural environment. The state's ecologic policy for the years of 2002-2010 was a document to support the activities of communes aimed at environmental protection. Long-term objectives are to be realized within the framework of the Strategy of the Sustainable Development of Poland by the Year 2025. In this article, an attempt was undertaken of a critical interpretation of American and European views in this area. The possibilities of the optimization and polyoptimization of the behaviors of individual and group inhabitants in the context of logistics chains modelling were highlighted. Standardized indexes will permit an effective assessment of the behaviors of a human or a given society referred to the economic (business) values in an area determined by the necessity of the functioning of ecologistic chains (this activity is proper to the objectives of designing and an objective assessment of the functioning of ecologistic chains).
\end{abstract}

Keywords: chain of deliveries; ecologistics; waste; commune; human behaviors

\section{Introduction}

The concept of a "chain-oriented" approach to logistics that is based on the idea of combining individual organizations into one or several intentionally "coupled" chains is interesting, particularly in economic and organizational aspects. Considering the fact that a chain of deliveries is a network of organizations involved, through their connections with suppliers and customers, in various processes and activities which generate a value in the form of products and services provided to end consumers [1], one cannot but observe that we deal with a combination of entities: suppliers, manufacturers, wholesalers, retailers, customers in any configurations possible, not excluding the repetitions of their occurrence. Each of the entities expects their own link of an added value after balancing; putting it specifically: each one of them wishes to earn "their" money or to obtain another value that is of an importance to them. The similarity of the research results obtained from British and Polish entrepreneurs [2,3] is interesting, namely that:

- a majority of enterprises consider the development of the chain of deliveries to be exquisitely essential, yet it is only some of them that correctly assess the potential offered by an effective operation of the chain of deliveries in the creation of a competitive position of the company on the market, 
- few companies correctly understand the benefits that result from an improvement of the chain of deliveries in the areas of costs, deliveries and the quality of operations,

- generally speaking, companies do not possess any detailed and complete strategies that are supported with clear and direct mechanisms required to implement a policy that ensures growth. This is reflected by a poor development of the chain of deliveries.

In the light of a continuous dispute involving views from an approach aimed at the use of logistics as a tool to reduce costs, to a holistic approach that indicates the "superiority" of the chain of deliveries as compared with logistics, one should think that no agreement will be reached in this area of the functioning of enterprises and economies. The dispute concerning the area of functioning, definitions, an indication of the trends (tendencies) of development leads gradually to the acceptance and implementation of logistic rules and, what follows from these, global logistic standards. Green logistics-ecologistics undoubtedly is a factor that puts the logistic chain in the environment area in order. In the further discussions, it is accepted that ecologistics is merely a certain stage in the evolutionary development of world logistics, whose purpose is an improvement of the flow of the stream of goods. This improvement is to be understood as an activity aimed at a streamlining of the use of raw materials and materials as well as a protection of the human's natural environment. The essential reasons of the formation of this direction include the following: the necessity to recover raw materials and materials, development of packaging and recycling technologies, an implementation of the rules of sustainable development in practice and the need to reduce the global waste mass.

For this specific area of the research, some research problems were identified. The major challenge is to find the answer for the question: what are the conditions of eco-logistics chains optimization process? For this general problem, the detailed questions were identified:

- what similarities and differences can be identified in the American and European approaches for the logistics chains?

- what factors influence on the functioning of reverse logistics in the analyse municipality in the area of municipal waste?

- to what extent can the collected data (case study) be used in the optimization of logistics chains?

\section{Methodology}

The purpose of this study is an identification of the determinants of an optimization process of ecologistic chains as well as an indication of the directions of their further improvement. The assessment was made based on an analysis of the world literature, the authors' own research, source data and development indexes in relation to the local government (case study). Eisenhardt [4] and Yin [5] emphasize that utilization of the case study method is suitable for the new research areas and allows one to understand the complex phenomenon.

The research process, introduced in this paper, were realized based on few stages: getting started, selecting cases, creating instruments and protocols, entering the field, analyzing data, shaping hypotheses, enfolding literature and reaching closure [4]. The diagnosis of the condition of the selected entity (a case study) served the purpose of a projection of a forecast of the conditions of its optimization and, due to its strategically universal nature, it may have an application in other objects and phenomena in the area of ecologistic operations.

\section{Case Study}

An assessment of the sustainable development of a commune [6,7] in the environmental area is not unambiguous and no model solution has been proposed (this is evidenced by the problems experienced by Polish communes, e.g., the problems of waste management). The purpose of the study was an identification of the conditions of the functioning of reverse logistics in the area of municipal waste. The research was carried out based on an analysis of the legislation, the statistical data from the Central Statistic Office, the source data from Szczecinek Commune [8] and the authors' 
own observations. When synthesizing the conclusions from the analysis of the legislation [9-11], it is to be stated that the maintenance of cleanness and tidiness is the responsibility of communal authorities. This is ensured through the following: creation of conditions to perform works connected with the maintenance of cleanness and tidiness in the commune's territory, ensuring the performance of these works through the creation of appropriate organizational units, preventing streets, squares and open area from getting dirty, determination of requirements for those who keep domestic animals in relation to safety and cleanness in public places, selective collection, segregation and storage of municipal waste, including dangerous waste which can be recycled, and cooperation with those enterprises that undertake activities in the scope of the management of this type of waste, ensuring the collection, transport and neutralization of the bodies of homeless animals or their parts, and cooperation with those entrepreneurs that undertake activities in this scope, and making available information to the local residents concerning the collection points of used up electric and electronic household appliances within the commune's territory. The supervision by the communal authorities of the observance of regulations in the scope of environmental protection in connection with waste is exercised by the municipal police that functions in the commune or through cooperation with the provincial environmental protection inspection. The long-term goals of waste management are realized within the framework of the Strategy of the Sustainable Development of Poland by the Year 2025. They adapt the current national ecological policy concept to the standards accepted in the 6th Programme of EU activities in the area of environmental protection.

The analysis of the waste management process in Szczecinek Commune is based on the logistics of the comparison of those costs that are essential for the achievement of the desired effect and the values of the resulting benefits. In the case of undertakings connected with environmental protection, in the commune in question, the costs of particular activities can be easily calculated. However, there are no appropriate methods and data to assess the values of benefits. Waste management in Szczecinek Commune is based on the collection of waste, its transport and neutralization (Figure 1). Households, craft and service enterprises are the sources of waste production. Waste from households constitutes $81 \%$ of the total mass of waste that is taken away. In this waste, the following elements were identified: fractions below $5 \mathrm{~mm}(24 \%)$, paper $(12 \%)$, organic waste $(45 \%)$ and PET foils (Poly (ethylene terephthalate)), glass, skin, textiles, wood (19\%). One-hundred-ten litre foil bags and $1.1 \mathrm{~m}^{3}$ containers are used for the purpose of mixed waste collection.

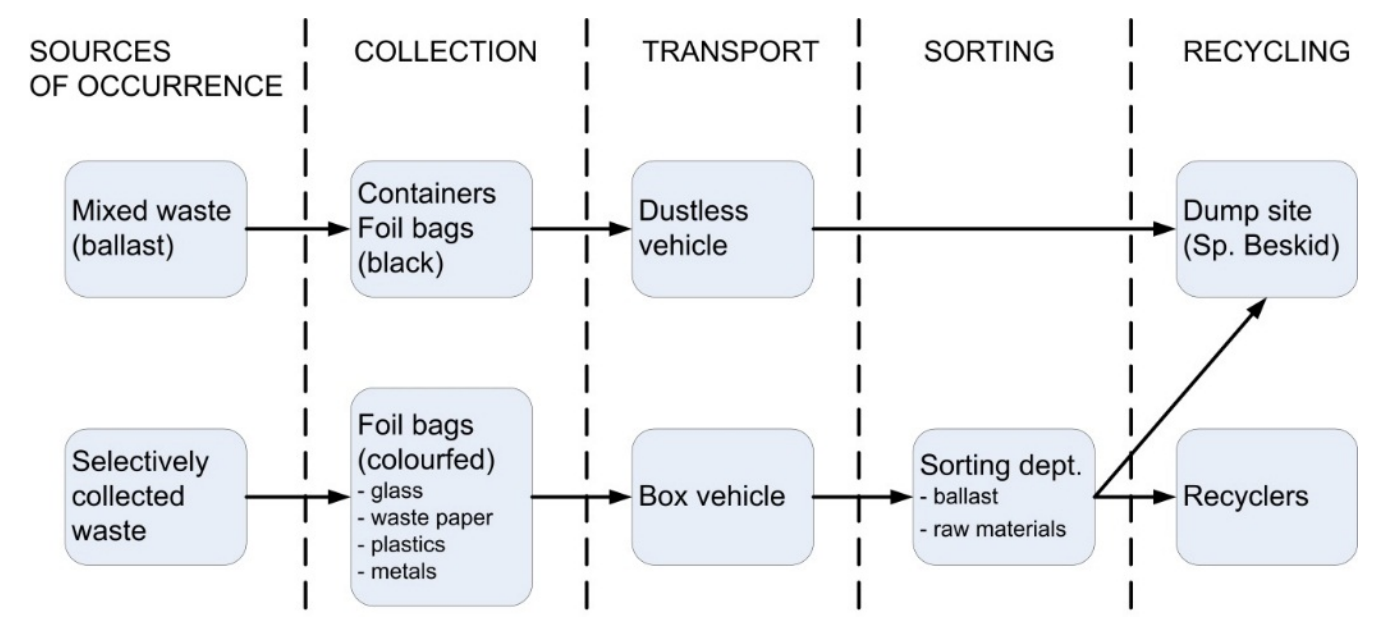

Figure 1. Diagram of the system of waste management in Szczecinek Commune. Source: Author's own study.

The transport of mixed waste was realized by the Municipal Services Department. On average, $81 \%$ of all the residents of Szczecinek Commune were covered by contracts. The waste, which meets the legal requirements, and which is administered by the Municipal Services Department, was stored 
at a dumping site (Trzesieka). The information concerning the use of the dumping site is presented in Table 1.

Table 1. List of the mass of waste collected in the years of 2006-2011.

\begin{tabular}{ccccccc}
\hline & $\mathbf{2 0 0 6}$ & $\mathbf{2 0 0 7}$ & $\mathbf{2 0 0 8}$ & $\mathbf{2 0 0 9}$ & $\mathbf{2 0 1 0}$ & $\mathbf{2 0 1 1}$ \\
\hline Trzesieka & 14,472 & 14,249 & 14,925 & 14,488 & 14,033 & 13,617 \\
Borne Sulinowo & 1805 & 1702 & 2291 & 2216 & 2295 & 1718 \\
Grzmiaca & 5697 & 4576 & 4798 & 4406 & 4556 & 3032 \\
Total & 21,974 & 20,527 & 22,014 & 21,110 & 20,884 & 17,367 \\
\hline
\end{tabular}

Source: Author's own study based on Environmental Protection Report of West Pomeranian Voivodeship in 2006-2007: IV Solid Waste Management, WIOŚ, Szczecin, 26, 2008; Environmental Protection Report of West Pomeranian Voivodeship in 2008, WIOŚ, Szczecin, 73, 2009; Environmental Protection Report of West Pomeranian Voivodeship in 2008-2008, WIOŚ, Szczecin, 22, 2011; Environmental Protection Report of West Pomeranian Voivodeship in 2006-2007: III Solid Waste Management, WIOŚ, Szczecin, 11, 2013 [12-15] (In Polish).

Taking into consideration the statistic number of residents in the period under examination (Figure 2), one needs to make a note of the diminishing mass of municipal waste produced by the residents (the year 2011 saw a decrease by almost $24 \%$ in comparison with the year 2008). This decrease cannot be justified by the demand and supply indexes of this local market. The waste selection process is proper: a systematic increase is being observed from $1.48 \%$ (2002) to $7.98 \%(2010)$ and $11.39 \%(2011)$. Solutions in relation to the collection and transport of waste need to be jointly analyzed due to direct interconnections between these two subsystems of waste management. Jointly, both subsystems are defined as a waste removal system; this involves both the removal of waste from the location where it is directly produced (a flat, a house, a technological process, etc.) to containers, as well as waste removal from settlement units (a quarter, a commune, a town, a region) or industrial plants, to utilization and neutralization facilities.

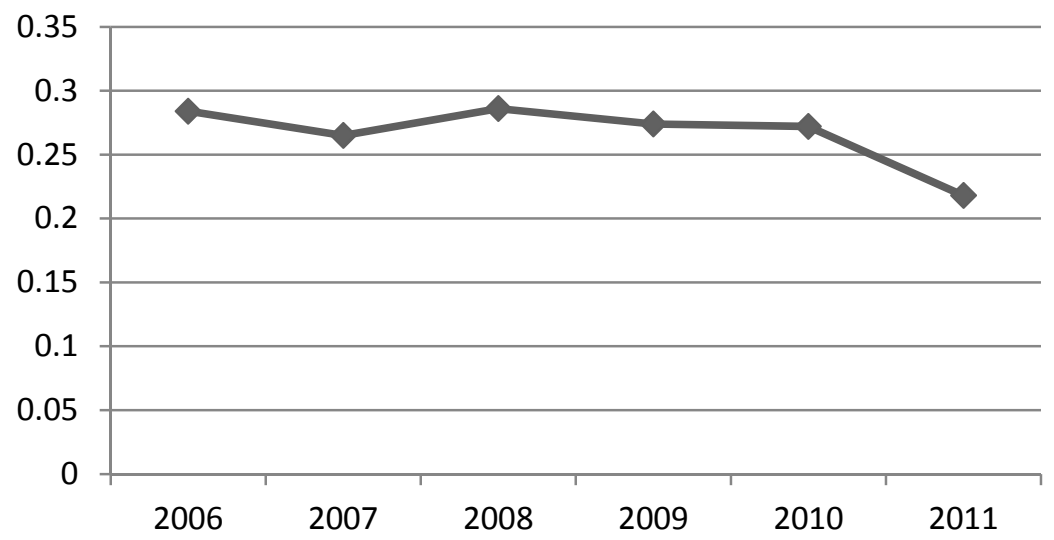

Figure 2. Average quantity of municipal waste per one resident $[\mathrm{Mg}]$. Source: Author's own study based on: Environmental Protection Report of West Pomeranian Voivodeship in 2006-2007: III Solid Waste Management, WIOŚ, Szczecin, 8, 2013 [15] (In Polish).

As a rule, an increase of the problem connected with waste management requires taking measures whose purpose is minimize the harmful environmental impact of waste while simultaneously implementing waste segregation. The presented studies demonstrate that in this specific commune, there has been an increase of service costs and fees in the context of legal changes; an almost $24 \%$ decrease of the mass of waste collected has been observed.

The analysis of the data presented above allows to identify four main groups of factors affecting the operation of reverse logistics in the area of municipal waste: 
- infrastructure-transport infrastructure, packages (like waste containers), IT and communication infrastructure (like information systems), warehouse infrastructure (like waste landfills, sorting plants);

- social impact-individual and group behaviors of residents of the municipality related to the realization of the municipal waste transfer tasks;

- economic factors-related to the level of the municipality efforts to build and maintain the infrastructure needed for the operation of reverse logistics and, on the other hand, related to the incomes from the sale of services for citizens;

- environmental influences-related to the ecosystem, where the inhabitants live; in this case, optimization of the eco-logistics chains is a peculiar challenge for seeking the balance between expenditures, revenues and the quality of the environment in the municipality.

An evolvement of the behaviors of organizations and customers is a rational issue that has been recognized by science and practice. In the process of this evolution, newer and newer solutions are appearing, and they function with their own life cycles; their purpose is to encourage a potential customer to exchange their money for the goods offered by an entrepreneur. Therefore, in the past decade, an increasing pressure has been observed in relation to a customer-oriented approach, and a creation of such conditions that are favorable to maintaining and even raising the security level of life in a given environment (ecosystem).

These activities are accompanied by the use of increasingly more refined technologies and a formation of law that protects the natural environment. Therefore, through a mental shortcut, a thesis can be proposed that the reason of logistics penetrating new areas of functioning is the use of such methods, techniques and tools that enable this; hence, there is this conclusion: the development of technique and technology extorts an extension of the area of cooperation between those entities that function on the market, including an extension of the area of customer services. This process will continue until a technologically and economically justified level of a vertical and horizontal integration has been reached (Figure 3).

The issues of reverse logistics have in principle been known since the very origins of their applications. Even the first suppliers would see to it when going to their customer's location to that a return freight is taken. It is a natural tendency to apply parity rules in shipment. Furthermore, if we take economic and social aspects into consideration, then in principle the process of seeking possibilities for the use of an artery of deliveries as a return way becomes a natural activity as such. In logistic practice, there are two fundamental trends in this area: an American one and a European one. The American trend is chiefly based on the idea of the returns of products (the sociological aspect is predominant here connected with the behavior of the American customer on the market and their tendency to return products purchased) [16-18]. This, however, does not mean that the idea accepted by Americans fails consider the remaining elements of logistic streams such as: stocks, packagings, waste, information etc. The definition of reverse logistics accepted by the Reverse Logistics Executive Council and the Council of Supply Chain Management Professionals, and which was popularized by Rogers and Tibben-Lembke demonstrates that it is a process of planning, introduction and cost effectiveness control of the flows of raw materials, stocks of production, finished articles and information connected with these: starting from the point of consumption to the original point, with the aim of a recovery of the values or an appropriate removal of these [19].

Therefore, in the American perspective, there are two fundamental trends: one indicating the necessity of "adding" an additional (alternative) channel with the processes of sorting, recycling and utilization that finish the life of a product; and the second trend, where products "return" through the same way (via the distribution channel) to the producer (an image of the so-called chain loop) [20]. A combination of loop areas demonstrates an involvement of the producer, cooperating manufacturers, suppliers, distributors and final customers in this process. The number of combinations is the permutation of the number of the participants in the loop of the delivery chain [21-23]. The issues of waste management: natural in the first case and forced in the second case is what connects the 
looped chain of deliveries with the added alternative channel of reverse logistics (an exclusion occurs here from the loop of a product which is suitable for any further processing or use) [24]. The practice of the applications of these solutions demonstrates that the use of reverse logistics in this approach can be realized in an individual system and with the use of the so-called returns centers (the function for reverse logistics is similar to logistic centres in delivery chains) [22,25].

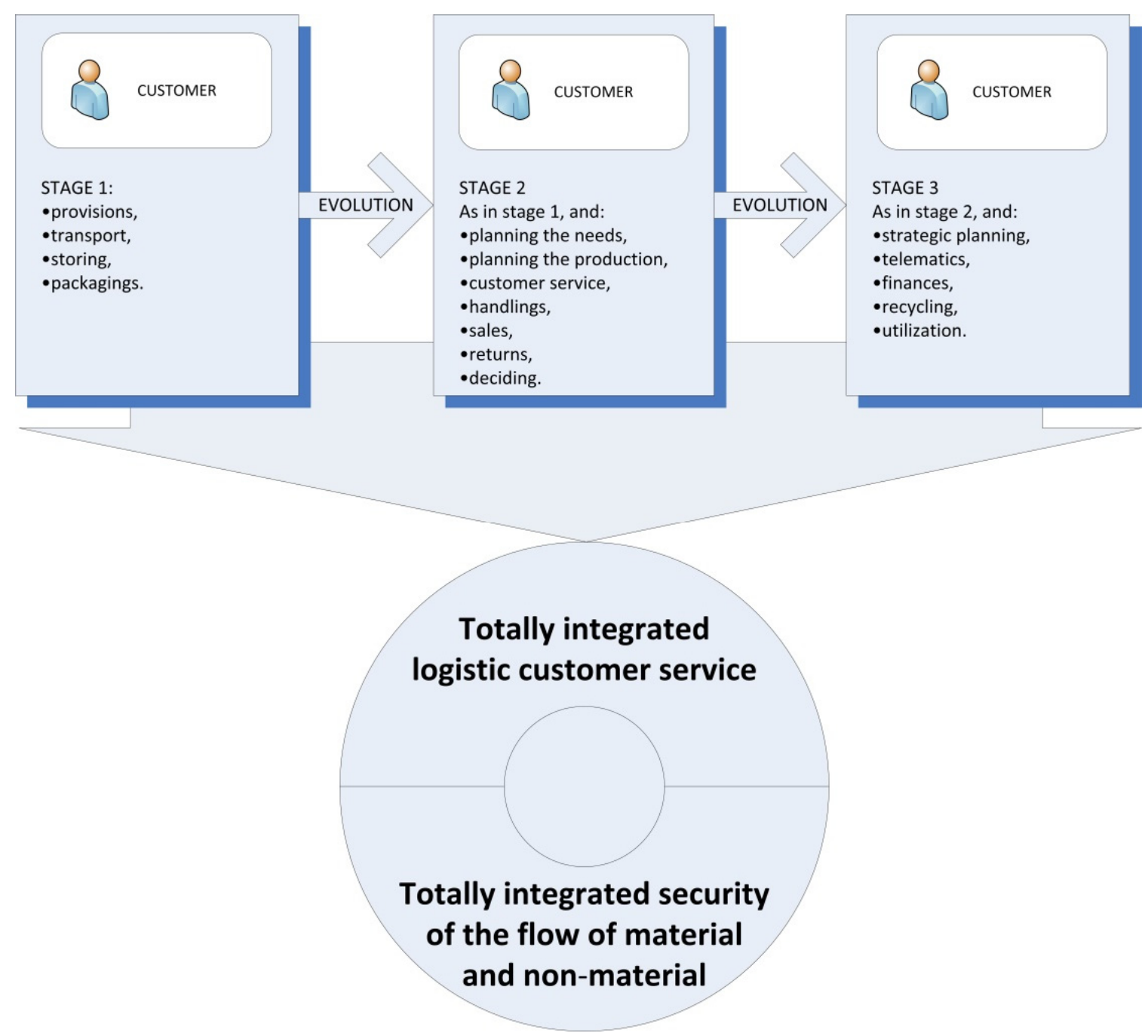

Figure 3. Evolution of the process of an integration of logistics in the customer environment. Source: author's own study.

The European trend considers reverse logistics a slightly differently than Americans. First of all, it should be observed that reverse logistics starts with the consumer who, when consuming a given good "produces" remnants from it and has the packaging at his/her disposal: at the same time, these are those objects which possess their specific economic value or constitute an ecological value. When considering the economic valjkue, we may pay attention to a number of aspects: the objects obtained can be again introduced into the circulation (recycling), or they can undergo a neutralization (utilization) processes. The ecological value is connected with the efforts on the part of the European society to preserve and protect the natural environment (ecologistics). Hence, the European trend in reverse logistics is primarily based on detailed legal regulations and well-exercised ecological education (pro-environmental behaviors). Germany is the leading state in the area of these activities in Europe. Germany classically indicates three areas of the functioning of reverse logistics, with the 
specification of the object of activities [26,27], the direction of the flow of goods and materials [28,29] and connections with the logistic system. Reverse logistics is a logistic subsystem aimed at planning and implementation of all the physical and information processes required for waste removal and processing [30-32]. The object of activities is waste that undergoes recycling or utilization. The direction of its flow (similarly as in the American direction) can be "looped", while the number of loop combinations is dependent on the number of those entities that participate in this activity in the logistic chain.

\section{Conditions of Ecologistic Chain Optimization}

The project of an ecologistic chain is a unique, targeted and coordinated task that possesses the defined time of commencement and completion. It is generally defined by a goal, a function scope (a product or a service), an execution period (dates), a budget (the summary costs of functioning) and a list of critical points. It deals with many activity areas. Those parameters that are the factors that determine the movement of real processes define its flow path. Assuming that we will treat the projected ecologistic process as an object of research composed of a number of systems, subsystems of activities (with a specification of their stages, operations and activities), we have at our disposal an entire scientific apparatus that permits an experiment in the final stage of the realization of the project. The following can be applied here for example: linear models, non-linear models, a standardization of input variables, an identification of multi-dimensional objects (with the method of correlation functions, a regression analysis and a factor analysis), an analysis of the experiment results, an optimization and poly-optimization as well as computer aided engineering research [33].

An analysis of the area of the functioning of ecologistic chains indicates that we deal with a multi-criterion space, where processes occur with a diversified degree of integration. Bearing in mind the growing significance of standardization that is perceived quantitatively and qualitatively, a strong tendency is to be observed to apply global solutions e.g. through the application of GS1 (Global System One) and EDI standards (Electronic Data Interchange), etc. in the strategic perspective of the development of logistics. The EU Project concerning interconnected logistics: MODULUSHCA, 2012-2015 [34] is promising in this area. It is related to the use of optimization models, the experience of industrial partners and the technical possibilities of laboratories to design prototype modular containers that will be used by $P \& G$ and Paste Italiane in their delivery chains. The growing role of the present-day information technologies in this process is unquestionable. The dynamics of development is confirmed by the evolution process of IT tools, which "describe" in an increasingly better manner the course of logistic chains. The problem in this area can be outlined on two basic planes: the first one concerning the diversified level of social development in every perspective: local, regional, national and global ones, and the second one concerning the philosophy of the use of ecologistic chains in the aspect of securing the functioning of production and manufacturing processes (JiT, JiS, ERP (Enterprise Resource Planning), DEM (Dynamic Enterprise Modeling), etc.).

When accepting a strategic approach to the first plane, it is difficult to find any uniform and coherent vision in the global reserves, one with a real support in facts that indicated global efforts aimed a truly sustainable social development. The efforts undertaken based on the features of species risks (ecology, global warming, etc.) in confrontation with the statistic data lose in an explicit manner: the Earth is resided by the continuously growing number of people.

A strategic approach to the social context implies, based on the economic facts and tendencies of the development of the applications of innovations in economy, changes that consist in a shift of the global decision making centres (the United States, the EU, China, India, Japan, Germany). This is an unavoidable process, one being closely connected with human capital. The recent years have seen a social stratification on a global level; this indicates real difficulties in the targeted and rational use of logistic tools equipped with apparatus and software that permits an optimization and poly-optimization of logistic process and chains. 
When accepting the application of the mechanisms of optimization and poly-optimization of logistic chains in the social aspect, one ought to indicate the need of a constant training and in-service training of producers and consumers as regards the methods and techniques of the formulation of goals, establishing of preferences and the value systems of a human (a group of humans), of quality assessment criteria and their weight etc. Understanding the place and role of a given human (a group of humans) in an economic system seems to be an essential strategic factor in this area. As it is indicated in Figure 4, the location of the place of logistic strategies on the global market is not unambiguous: we deal with a diversified permeance of three layers: strategic, tactical, and operational ones. However, in each case, in order to compete rationally on the market, a precise definition is essential of the vision, mission and goals expressed in quantitative and qualitative perspectives and so that it can be "processed" mathematically. The approach presented permits an optimization and poly-optimization of the management of ecologistic chains, their designing and improvement (the engineering of logistic processes), as well as an application of MCDM (Multiple-criteria decision-making) type methods. When possessing more and more perfected mathematical models that are supported by the dynamically developing IT sector, one may believe that the occurring non-linear limitations and discontinuities in logistic processes and chains will not cause any increase of the level of risk in relation to the determination of the goal path trajectory (a goal bundle).

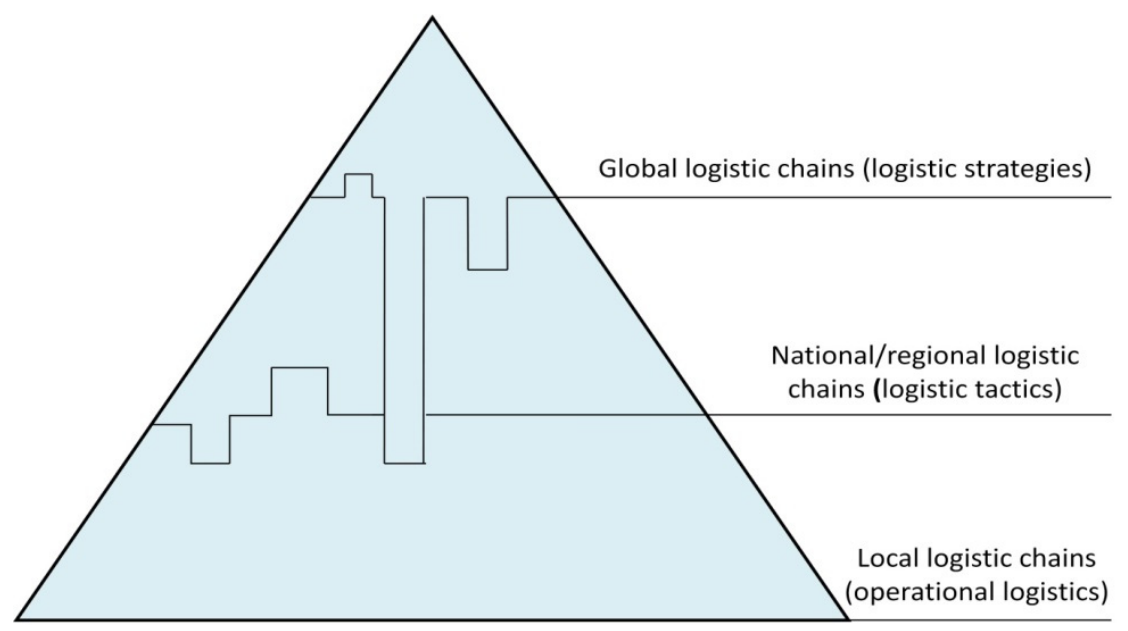

Figure 4. Place of logistic strategies in a global perspective. Source: Author's own study.

In principle, the strategic aspect of the philosophy of the use of logistic chains in the production technology area concerns two concepts: the Asian one and the Euro-American one. It is based on three transportation methods of raw materials and materials in production: the pushing method, the sucking method and the mixed method. In accordance with these methods, JiT type concepts that have been developed, which secure the functioning of production that uses the sucking technology, come down in their idea to the "dragging" of one piece of product through the entire chain: from the supplier to the customer [35]. This philosophy "forces" each participant of the logistic chain to apply these assessment criteria of the effectiveness of operation, which come down to a continuous process reduction of the number of errors and to raising of the quality level in all the areas: material, capital, human, energy etc. The ERP and DEM class methods strategically "bind" the supplier, manufacturers and customers by gradually offering to them an integration plane with an increasing number of applications that allow a simulation of those solutions that are acceptable in business. The movement of raw materials and materials (the pushing method) forced by the planned needs of the successive chain links is the core of integration. Those procedures that take into account the theory of limitations [36] or the system of sequencing in the chain links JiS (Just in Sequencis) developed by PSI AG are more and more boldly entering between these polarized concepts. Bearing the above mentioned concepts in mind, it is to 
be stated that they are strategically aimed at an inclusion of increasing numbers of the elements of the environment both "in front" and "at the back" of the chain as well as "backwards". Ecologistic chains that have been depleted in the processes of Lean Management, Lean Manufacturing and Lean Logistics types find their way in an integrated space where, in a different configuration, they are again "collectively" (for a given task, a given purpose or a stream of purposes) processed with IT tools in the context of their optimization and poly-optimization. In the strategic context, an optimization and poly-optimization process of ecologistic chains comes down to the following:

- determination of the system of values that provides answers to basic questions:

- how was the notion of quality defined in the area of ecologistics?

- what are the parameters of the standard and the tolerance limits of these parameters?

- what dependences (relations) occur between the parameters?

- what are the criteria of the waste producer assessment?

- what are the criteria of the waste consumer assessment?

- what are the superior criteria of ecologistics optimization?

- formulation of the objectives of optimization or poly-optimization that consist in:

- determination of a set of solutions (variants of solutions),

- determination (identification) of decision variables that lead to the selection of an optimal variant or a set of poly-optimal (compromise) solutions,

- $\quad$ solutions of optimization and poly-optimization tasks that come down to:

- formulation of an ecologistic chain model,

- reference of an ecologistic chain model to the appropriate mathematical model,

- choice of an appropriate ecologistic chain model for an optimization or poly-optimization method,

- optimization or poly-optimization of an ecologistic chain,

- control and coordination of solutions obtained through a feedback of the stages presented above,

- completion of an optimization or poly-optimization process: a projection of the best solution.

\section{Conclusions}

The present-day ecologistic chains require an application of more and more refined technologies and tools in all the areas of their functioning: from the social sphere to the production sphere, while maintaining the idea of their feedback. This implies the need of a strategic approach to the issues of an optimization and poly-optimization of ecologistic chains. When looking from a strategic perspective at the subject of the discussion - the human - we perceive him/her both as an individuality and as an element of a community. Hence, an optimization of his/her behaviors and a poly-optimization of group behaviors undoubtedly is a significant challenge, one which requires an application of appropriate indexes; such indexes which are comparable (e.g., between communes within a district, a province and a country). Standardized indexes will permit an effective assessment of the behaviors of a human or a given society referred to the economic (business) values in an area determined by the necessity of the functioning of ecologistic chains (this activity is proper to the objectives of designing and an objective assessment of the functioning of ecologistic chains). An allocation of ecologistic chains to these behaviors leads to the need to model this space, which with a reference to the developmental trends of supporting technologies extorts a rational preparation of the producers and consumers of waste to their effective service. An application to an increasing extent of standardization-until the level of a total standardization has been reached that allows an effectively use of optimizing tools-constitutes an essential element of this process. 
Author Contributions: Jerzy Korczak has established the concept and prepared methodology as well as the major assumptions for case study. Kinga Kijewska has prepared case study. In addition, she participated in section "Conditions of Ecologistic Chain Optimization". Stanisław Iwan was responsible for the final paper integration and edition as well as the preparing of conditions of ecologistic chain optimization.

Conflicts of Interest: The authors declare no conflict of interest.

\section{References}

1. Christopher, M. Logistics and Supply Chain Management: Strategies for Reducing Costs and Improving Service; Financial Times-Prentice Hall: London, UK, 1998; Volume 14.

2. Taylor, D. Supply chain development: Realities in the UK metals industry. Logistics Research Network 2001. In Proceedings of the 6th Logistics Research Network Annual Conference, Edinburgh, UK, 13-14 September 2001; School of Management at Heriot-Watt University UK: Edinburgh, UK, 2001; p. 510.

3. Zawadzka, D.; Korczak, J. The Middle Pomerania—Society, Economy. Selected Problems; PTE: Koszalin, Poland, 2008; pp. 229-244. (In Polish)

4. Eisenhardt, K.M. Building Theories from Cases Study Research. Acad. Manag. Rev. 1989, 14, 532-550.

5. Yin, R. Case Study Research; Sage Publications: Beverly Hills, CA, USA, 2003; p. 2.

6. Hełdak, M.; Raszka, B. Evaluation of the Local Spatial Policy in Poland with Regard to Sustainable Development. Pol. J. Environ. Stud. 2013, 22, 395-402.

7. Dobrzańska, B.M. The Strategic Planning of Sustainable Development Environmentally Valuable Communes; Wydawnictwo Uniwesytetu w Białymstoku: Białystok, Poland, 2007; p. 133.

8. Szczecinek Commune. Available online: http://www.bip.szczecinek.pl/?c=363 (accessed on 3 March 2016).

9. Sejm, R.P. The law on the maintenance of cleanliness and order in the municipalities and certain other laws. Dz. U. 2011, 152, 5-17.

10. The Council of the European Union. Directive of The Council of Europe 1999/31/UE. Available online: http:/ / eur-lex.europa.eu/legal-content/PL/TXT/PDF/?uri=CELEX:31999L0031\&from=PL (accessed on 3 March 2016).

11. The European Parliament. Directive of The Council of Europe 2008/98/UE. Available online: http:/ / eur-lex. europa.eu/legal-content/PL/TXT/PDF/?uri=CELEX:32008L0098\&from=EN (accessed on 3 March 2016).

12. Jurkowska, K. Environmental Protection Report of West Pomeranian Voivodeship in 2006-2007: IV Solid Waste Management; WIOŚ: Szczecin, Poland, 2008. Available online: http://www.wios.szczecin.pl/ bip/files/555DC13F6D5F458F851257DE287DDD82/IV_Gospodarowanie_odpadami.pdf (accessed on 3 March 2016).

13. Environmental Protection Report of West Pomeranian Voivodeship in 2008; WIOŚ: Szczecin, Poland, 2009. Available online: http:/ / www.wios.szczecin.pl/bip/files/70110C0414E14F0B98DCDB54B50F0FA3/Stan\%20 srodowiska\%20w\%202008r.pdf (accessed on 3 March 2016).

14. Environmental Protection Report of West Pomeranian Voivodeship in 2008-2009: III Solid Waste Management; WIOŚ: Szczecin, Poland, 2011. Available online: http://www.wios.szczecin.pl/bip/files/ 5FB2E13F86DD4F45BCEF65576F892BC4/III_Gospodarowanie_Odpadami.pdf (accessed on 3 March 2016).

15. Jurkowska, K. Environmental Protection Report of West Pomeranian Voivodeship in 2006-2007: III Solid Waste Management; WIOŚ: Szczecin, Poland, 2013. Available online: http://www.wios.szczecin.pl/bip/files/ 4D67555E991F4E2D9A071D8BBE05EDFB/III\%20Gospodarowanie\%20odpadami.pdf (accessed on 3 March 2016).

16. Stock, J. Reverse logistics. Council of Logistics Management; Council of Logistics Management: Oak Brook, IL, USA, 1992; Volume 7.

17. Lambert, D.L.; Stock, J.R.; Ellram, L.M. Fundamentals of Logistics Management; McGraw-Hill: Boston, MA, USA, 1997; Volume 20.

18. Fleischmann, M. Quantitative Models for Reverse Logistics; Springer: Heidelberg, Germany, 2001; Volume 5.

19. Rogers, D.S.; Tibben-Lembke, R.S. Going Backwards: Reverse Logistics Trends and Practices; University of Nevada, Center for Logistics Management, Reverse Logistics Executive Council: Reno, NV, USA, 1998; Volume 262.

20. Ballou, R.H. Business Logistics/Supply Chain Management, 5th ed.; Pearson Prentice Hall: Upper Saddle River, NJ, USA, 2004; pp. 7-8.

21. Rogers, D.S.; Lambert, D.M.; Croxton, K.L. The Returns Management Process. Int. J. Logist. Manag. 2002, 13, 1-18. [CrossRef] 
22. Blumberg, D.F. Introduction to Management of Reverse Logistics and Closed Loop Supply Chain Processes; CRC Press: Boca Raton, FL, USA, 2005; pp. 13-14.

23. Wells, P.; Seitz, M. Business Models and Closed Loop Supply Chains: A typology. Supply Chain Manag. 2005, 10, 249-251. [CrossRef]

24. Ross, D.F. The Intimate Supply Chain; CRC Press: Boca Raton, FL, USA, 2008; Volume 87.

25. Tibben-Lembke, R.S. Life After Death: Reverse Logistics and the Product Life Cycle. Int. J. Phys. Distrib. Logist. Manag. 2002, 32, 224-225. [CrossRef]

26. Schönsleben, P. Integrales Logistikmanagement; Springer: Berlin, Germany, 1998; Volume 14.

27. Rinschede, A.; Wehking, K.-H. Entsorgungslogistik. I. Grundlagen, Stand der Technik; Erich Schmidt Verlag: Berlin, Germany, 1991; Volume 21.

28. Hirschberger, D.; Reher, I. Entsorgungslogistik als unternehmensübergreifendes Konzept; RKW-Handbuch Logistik; Erich Schmidt Verlag: Berlin, Germany, 1996; p. 5.

29. Spitzenpfeil, T. Die vierte Dimension der Logistik. Tech. Manag. 1990, 39, 21-24.

30. Wehking, K.H. Entsorgungslogistik am Beispiel Sonderabfall. Müll und Abfall 1989, 21, 592-597.

31. Werner, W. Entsorgungslogistik, Beschaffung aktuell. Beschaffung aktuell 1990, 6, 54.

32. Pfohl, H.C.H.; Stölzle, W. Entsorgungslogistik, Handbuch des Umweltmanagements. Anforderungs-und Leistungsprofile von Unternehmen und Gesellschaft; Beck: München, Germany, 1992.

33. Korczak, J. Logistics. Infrastructure. Network. Strategies; Politechnika Koszalińska: Koszalin, Poland, 2013; pp. 113-144.

34. Montreuil, B.; Meller, R.D.; Ballot, E. Towards a Physical Internet: The Impact on Logistics Facilities and Material Handling Systems Design and Innovation; Material Handling Institute: Charlotte, NC, USA, 2010; pp. $305-327$.

35. Liker, J.K. The Toyota Way; MT Biznes: Warszawa, Poland, 2005; p. 480.

36. Goldratt, E. The Goal: A Process of Ongoing Improvement, 3rd ed.; Mint Books: Warszawa, Poland, 2007 ; p. 318.

(C) 2016 by the authors; licensee MDPI, Basel, Switzerland. This article is an open access article distributed under the terms and conditions of the Creative Commons by Attribution (CC-BY) license (http:/ / creativecommons.org/licenses/by/4.0/). 